\title{
Debris-Flow Hazards in the Blue Ridge of Virginia
}

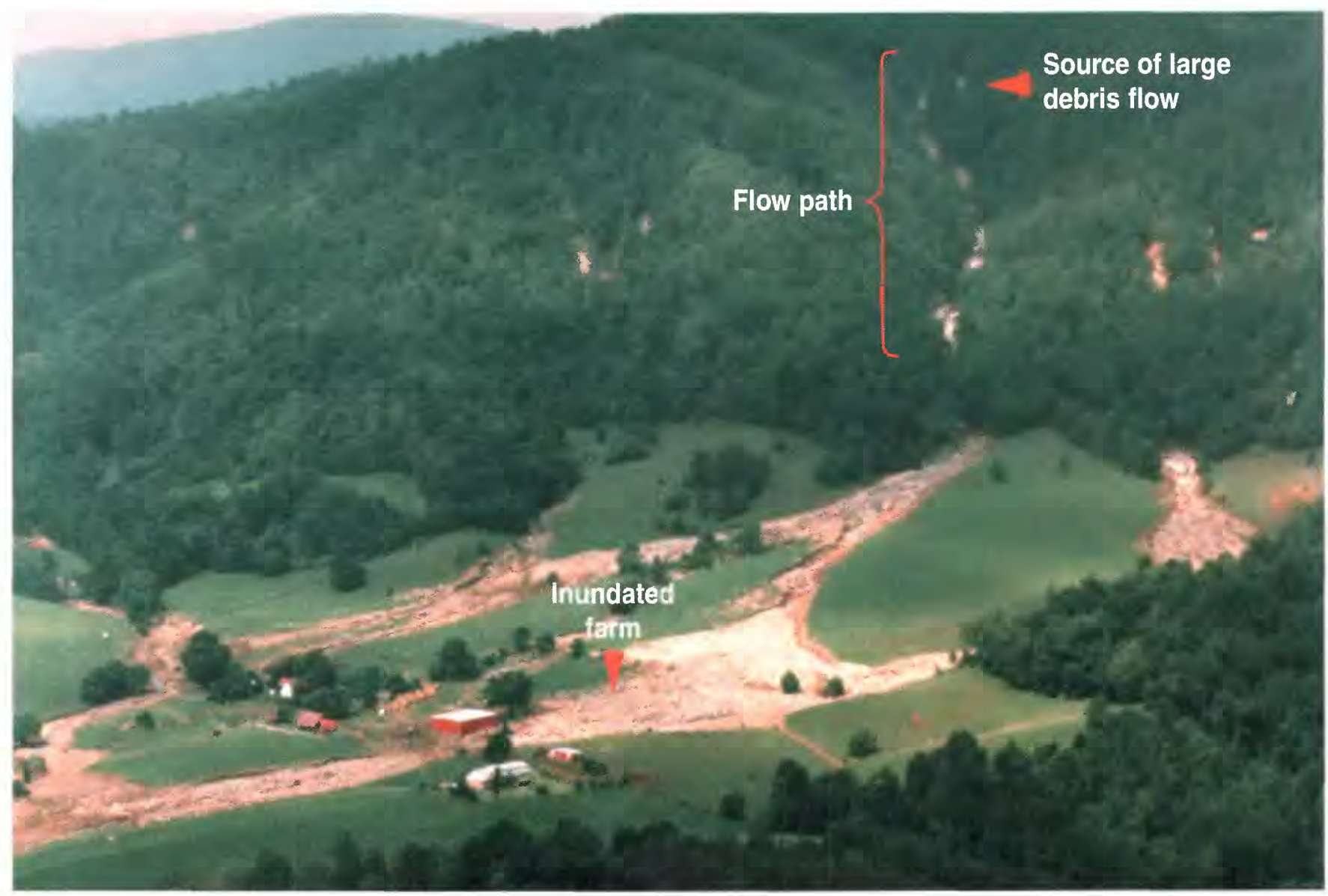

Numerous debris flows scarred the foothills of the Blue Ridge in Madison County, Virginia, after the devastating storm of June 27, 1995. These debris flows, which began on steep slopes, moved rapidly down channels in the mountains. Small flows joined to form larger flows and spread mud, boulders, and other debris in valleys, inundating residents' homes and farms. (Photograph copyright by Kevin Lamb, 1995; published with permission.)

The foothills of the Blue Ridge 1 province in central Virginia are dotted with working farms along meandering rivers. The setting is peaceful to the casual observer, but on closer inspection there are signs of past violent weather and geologic events. Massive boulders found at the base of the foothills are vivid reminders of catastrophic large landslides and debris flows that have sculpted the local landscape. Evidence of past landslides, like these boulders, can be found in the foothills of the Blue Ridge from Pennsylvania to Georgia.

In the summer of 1995, a major landslide event occurred in Madison County, Virginia. During an intense storm on June 27 th, 30 inches of rain fell in 16 hours. In the mountainous areas of the county, rainsaturated landslides known as debris flows were triggered by the hundreds. The Rapidan, Robinson, and Conway Rivers flooded the lowlands, wreaking widespread destruction (see map on page 3). Because of the severity of the storm's effects, rural communities such as Graves Mill were isolated when bridges, roads, and power and telephone lines failed. The full extent of the damage was not recognized until aerial surveys were made several days later. The county was then declared a Federal disaster area by the President. The Federal Emergency Management Agency, U.S. Army Corps of Engineers, National Park Service, Virginia Department of Transportation, the
U.S. Geological Survey, and other agencies offered assistance in recovering from the devastation and are studying ways to reduce losses from future such events.

The most severe effects of the storm occurred in the areas of heaviest rainfall. In addition to flooding along the main rivers and streams, landslides on steep hillsides rapidly transformed into fast-moving debris flows. Ultimately scientists identified hundreds of individual debris flows. One flow near Graves Mill, Virginia, traveled nearly 2 miles, and an eyewitness estimated that it moved at a speed approaching 20 miles per hour. Damage to manmade structures commonly occurred where debris flows emerged from mountain 
channels, spreading large quantities of rocky material. Houses and barns were inundated or crushed by the debris. Pastures and cornfields were covered, and livestock perished. Many trees, stripped of their bark, branches, and leaves, were carried into swollen streams and rivers and acted as battering rams against buildings and bridges. Such debris greatly increased the destructive power of the flood waters. In addition, debris from the mountain channels was carried into streams and rivers, contributing to downstream flooding. One woman was killed by a debris flow near Criglersville, Virginia, and seven other fatalities were caused by flooding elsewhere in the State. Total damage from the storms was estimated at over $\$ 100$ million.

Historical records tell us that destructive landslides and debris flows in the Appalachian Mountains occur when unusually heavy rain from hurricanes and intense storms soaks the ground, reducing the ability of steep slopes to resist the downslope pull of gravity. During Hurricane Camille in 1969 , such conditions generated debris flows in Nelson County, Virginia, 90 miles south of Madison County. The hurricane caused 150 deaths, mostly attributed to debris flows, and more than $\$ 100$ million in property damage. Likewise, 72 hours of storms in Virginia and West Virginia during early November 1985 caused debris flows and flooding in the Potomac and Cheat River basins that were responsible for 70 deaths and $\$ 1.3$ billion in damage to homes, businesses, roads, and farmlands.

Scientists have documented 51 historical debris-flow events between 1844 and 1985 in parts of the Appalachians - most of them in the Blue Ridge area. Recent studies of deposits exposed in stream channels during the 1995 storms in Madison County found evidence of prehistoric de- bris flows. Radiocarbon dating of plant remains from debris-flow deposits near Graves Mill indicates that these processes have occurred there repeatedly over the last 34,000 years.

Scientists from the U.S. Geological Survey and from cooperating universities, including Princeton University and the University of Virginia, have developed an inventory of landslides, debris flows, and flooding from the storm of June 27, 1995, by using aerial photography, field investigations, rainfall measurements from rain gages, and National Weather Service radar observations. This inventory and a debris-flow hazard map that was prepared from it will be used to help understand the conditions that can lead to disasters like the floods and debris flows caused by the 1995 summer storms in Virginia and to suggest methods of mitigating the effects of such events in the future.

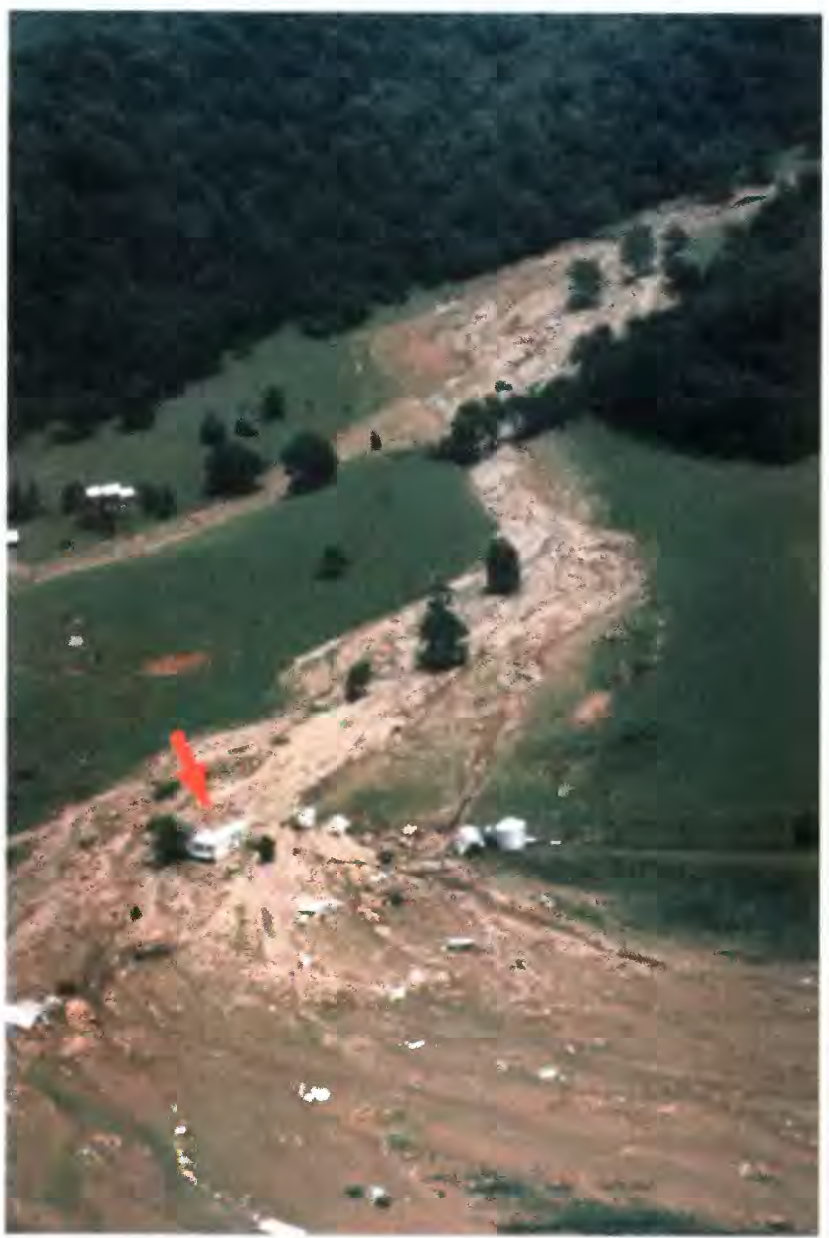

This debris flow near Graves Mill was triggered during the storm of June 27, 1995, in Madison County, Virginia. It emerged from a mountain channel (at upper right) and deposited rocky debris on this farm. At 11:30 am the powerful debris flow moved the two-story farmhouse (arrow) more than 30 feet from its foundation. The family in the house survived because they took refuge in the second story. Several other structures on the farm were destroyed. (Photograph copyright by Kevin Lamb, 1995; published with permission.)

\section{What Are Debris Flows?}

Some landslides move slowly and cause damage gradually, whereas others move so rapidly that they can destroy property and take lives suddenly and unexpectedly. Debris flows (also referred to as mudslides, mudflows, or debris avalanches) are a common type of fast-moving landslide that generally occurs during intense rainfall on water-saturated soil. They usually start on steep hillsides as soil slumps or slides that liquefy and accelerate to speeds as great as 35 miles per hour or more. They continue flowing down hills and into channels and deposit sand, mud, boulders, and organic material onto more gently sloping ground. Their consistency ranges from watery mud to thick, rocky mud (like wet cement), which is dense enough to carry boulders, trees, and cars. Debris flows from many different sources can combine in channels, where their destructive power may be greatly increased. 
An intense storm on June 27, 1995, dropped 30 inches of rain on the foothills of the Blue Ridge in Madison County, Virginia. This storm triggered hundreds of debris flows and caused widespread flooding. Some rural communities were isolated when bridges, roads, and powerlines failed. Devastation was so great that the President declared the county a Federal disaster area. The track of the storm's center during its most damaging phase closely matches the areas where most of the debris flows occurred. As can be seen on this map, small debris flows move downslope following drainage channels and often merge to form larger flows.

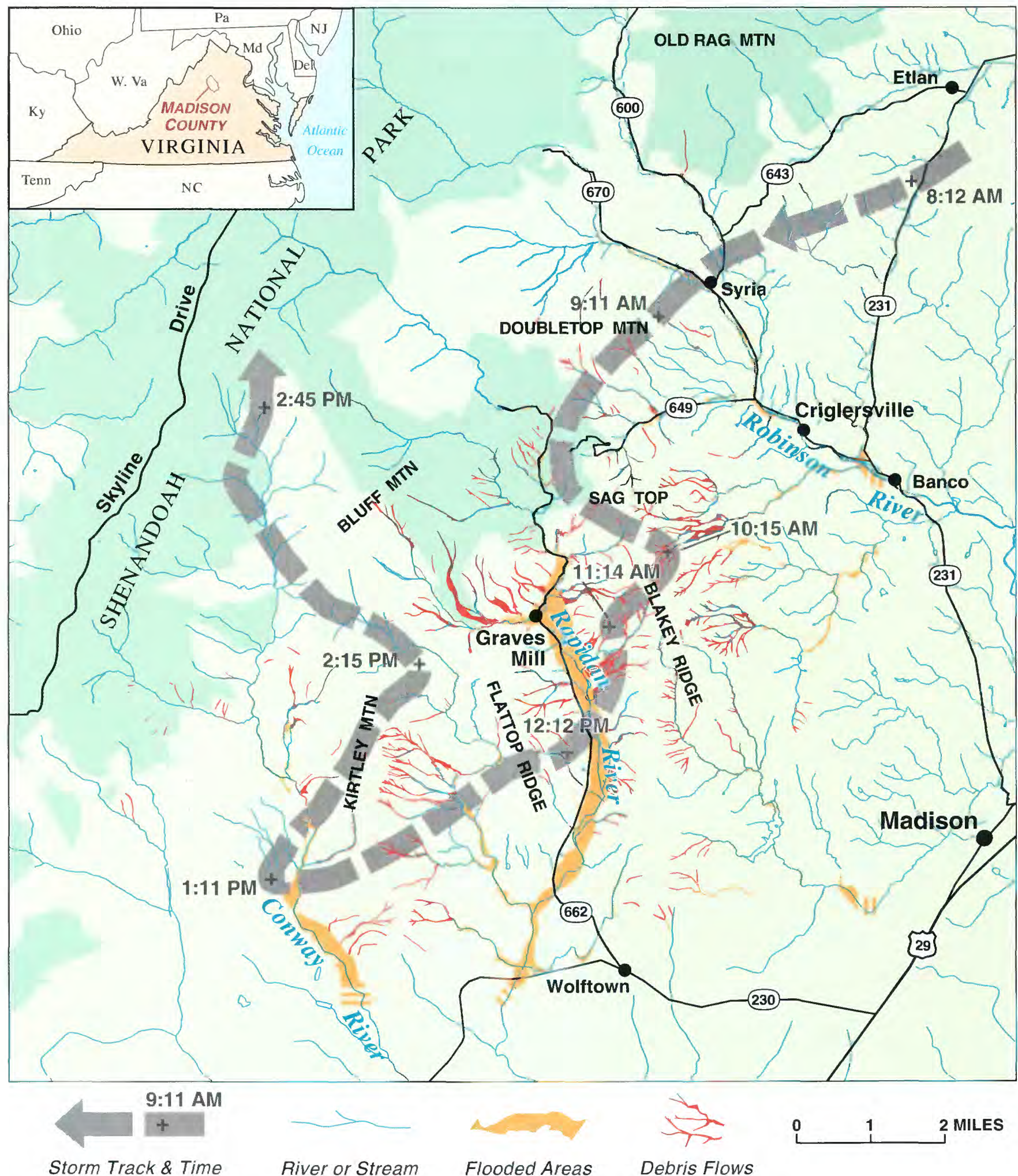




\section{What You Can Do If You Live Near Steep Hills}

\section{Prior to Intense Storms}

1. Become familiar with the land around you. Learn whether debris flows have occurred in your area by contacting local officials, State geological surveys or departments of natural resources, and university departments of geology. Slopes where debris flows have occurred in the past are likely to experience them in the future.

2. Support your local government in efforts to develop and enforce land-use and building ordinances that regulate construction in areas susceptible to landslides and debris flows. Buildings should be located away from steep slopes, streams and rivers, intermittent-stream channels, and the mouths of mountain channels.

3. Watch the patterns of storm-water drainage on slopes near your home, and note especially the places where runoff water converges, increasing flow over soil-covered slopes. Watch the hillsides around your home for any signs of land movement, such as small landslides or debris flows or progressively tilting trees.

4. Contact your local authorities to learn about the emergency response and evacuation plans for your area, and develop your own emergency plans for your family and business.

\section{Sources of Technical Information}

Landslide and debris-flow hazards caused by the June 27, 1995, storm in Madison County. Virginia (includes discussion of mitigation options), by G.F. Wieczorek, P.L. Gori, R.H. Campbell, and B.A. Morgan. U.S. Geological Survey Open-File Report 95-822, 1995, $33 \mathrm{p}$.

Preliminary inventory of debris-flow and flooding effects of the June 27, 1995, storm in Madison County, Virginia, showing time sequence of positions of stormcell center, by G.F. Wieczorek, B.A. Morgan, R.H. Campbell, R.C. Orndorf, W.C. Burton, C.S. Southworth, and J.A. Smith. U.S. Geological Survey Open-File Report 96-13, 1996, 8 p., 1 map (1:24.000 scale).

When the Earth moved in Madison County, by W.C. Burton. Washington Post, June 12 , 1996.

Geomorphic studies of the storm and flood of November 3-5, 1985, in the Upper Potomac and Cheat River basins in West Virginia and Virginia, by R.B. Jacobson, U.S. Geological Survey Bulletin 1981, 1993, 207 p.

Debris flows/avalanches: Process, recognition, and mitigation, edited by J.E. Costa and G.F. Wieczorek. Geological Society of America, Reviews in Engineering Geology, v. VII, 1987.236 p.

Landslide loss reduction: A guide for State and local government planning, by R.L. Wold, Jr., and C.L. Jochim. Federal Emergency Management Agency Earthquake Hazards Reduction Series 52, 1989, $50 \mathrm{p}$.

\section{During Intense Storms}

1. Stay alert and stay awake! Many debris-flow fatalities occur when people are sleeping. Listen to a radio for warnings of intense rainfall. Be aware that intense short bursts of rain may be particularly dangerous, especially after longer periods of heavy rainfall and damp weather.

2. If you are in areas susceptible to landslides and debris flows, consider leaving if it is safe to do so. Remember that driving during an intense storm can itself be hazardous. If you remain at home, move to a second story if possible.

3. Listen for any unusual sounds that might indicate moving debris, such as trees cracking or boulders knocking together. A trickle of flowing or falling mud or debris may precede larger landslides. If you are near a stream or channel, be alert for any sudden increase or decrease in water flow and for a change from clear to muddy water. Such changes may indicate landslide activity upstream, so be prepared to move quickly. Don't delay! Save yourself, not your belongings.

4. Be especially alert when driving. Embankments along roadsides are particularly susceptible to landslides. Watch the road for collapsed pavement, mud, fallen rocks, and other indications of possible debris flows.

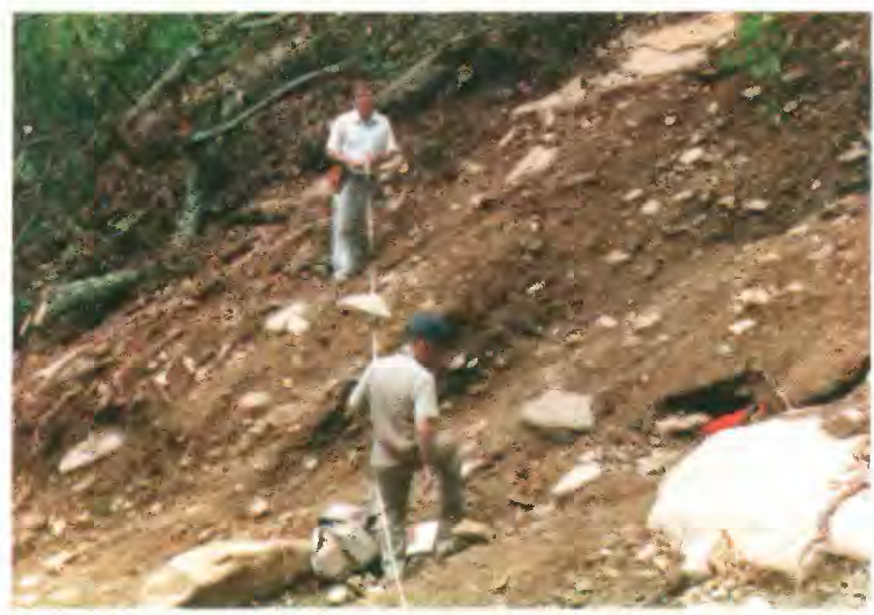

U.S. Geological Survey scientists measuring a fresh debris-flow scar near Graves Mill in Madison County, Virginia, after the storm of June 27, 1995.

Paula L. Gori and William C. Burton

For more information, please contact:
National Landslide Information Center
U.S. Geological Survey, Mail Stop 966
Box 25046, Federal Center
Denver, CO 80225
1-800-654-4966
highland@ gldvxa.cr.usgs.gov
U.S. Geological Survey Fact Sheet-159-96
1996

